\title{
Chemical analysis of extracting transition metal oxides from polymetallic ore by sulphate process
}

\author{
Otgon-Uul Enkh-Uyanga ${ }^{l}$, Baatar Munkhtsetseg ${ }^{{ }^{*}}$, Urtnasan Urangoo ${ }^{2}$, Enkhtur Tserendulam ${ }^{l}$ and Davaadorj Agiimaa $^{l}$ \\ ${ }^{1}$ Chemistry Department, Ulaanbaatar State University, 13343, U1 aanbaatar, Mongolia \\ ${ }^{2}$ Charles Sturt University, Canberra 2602 ACT, Australia
}

\begin{abstract}
In this research work we attempt to improve the purity of polymetallic ores in Mongolia whilst developing practical applications of its refinement processes and this paper presents the results of chemical research of extracting transition metal titanium oxides, ferrous oxide and rare earth oxides from polymetallic ore. Thereby, chemical and mineral analysis of polymetallic ore is carried out basis of responses to the support process at various degrees of water whereas transition metal sulphates solubility differ. As a result of sulphate and resulphurization process we have extracted anatase with 62.5 percent titanium dioxide and brookite mineral with 89.6 percent of titanium dioxide as well as mineral with 83.8 percent of ferrous oxide hematite and rare earth oxides with 57.6 percent of cerium oxide. These oxides are identified under various conditions in the thermal processing. The morphology structure and chemical content compound of the mineral has been verified as a result of the XRF, XRD, SEM-EDX analysis.
\end{abstract}

Keywords: polymetallic ore, anatase, brookite, hematite, rare earth oxides

Introduction: Mongolia is a country rich in polymetallic ores. There is an increased demand for research of the processing polymetallic ores by removing impurities and forming refined minerals as transition metals have found countless applications in many industries. Therefore, this research attempts to improve the purity of such ores whilst developing practical applications of refinement process.

Polymetallic ores are complex materials containing several metals and metal compositions. As metals and metal compositions in the ore increases, technology to extract these metals become more difficult and complicated [1]. However transition metal minerals such as titanium, iron can be recovered by the methods; leaching minerals from ores using an acidic solution such as sulphuric acid [2]. Titanium dioxide can be produced from high content of titanium such as an ilmenite mineral, which is treated with the sulphuric acid $\left(\mathrm{H}_{2} \mathrm{SO}_{4}\right)$, chemical reaction $(1,2)$ follow as:

$$
\begin{aligned}
\mathrm{FeTiO}_{3}+\mathrm{H}_{2} \mathrm{SO}_{4}+2(\mathrm{n}-1) \mathrm{H}_{2} \mathrm{O} & =\mathrm{TiOSO}_{4} \cdot \mathrm{nH}_{2} \mathrm{O}+\mathrm{FeSO}_{4}+\mathrm{nH}_{2} \mathrm{O}(1) \\
\mathrm{TiOSO}_{4}+2 \mathrm{H}_{2} \mathrm{O} & =\mathrm{TiO}_{2} \cdot \mathrm{H}_{2} \mathrm{O}+\mathrm{H}_{2} \mathrm{SO}_{4}(2)
\end{aligned}
$$

First of all, we determined its optimal condition to extract transition metal by sulphate method [3] and then titanium dioxide and other minerals have extracted whilst removing related elements during sulphate processes of the ore sample, which has been repeated. Thereby, chemical and mineral analysis of polymetallic ore is carried out basis of responses to the support process at various degrees of water whereas transition metal sulphates solubility differ.

There are certain solutes, which have independently fair degree of solubility to temperature change. One of the them is cerium(III) sulphate that has lesser degree of solubility at temperature increases. Rare earth elements belonged in cerium group have very good degree of solubility in water at $+2^{0} \mathrm{C}$ temperature [4].

The solubility of ferrous sulphate increases with an increase in sulphuric acid concentration and steeply decreases with an increase in temperature in pure water [5].

\section{Experimental}

Materials and methods: As a research raw material is 2306.33 hectare Orkhontuul either "Anand" polymetallic ore in the Orkhontuul soum has selected. This ore is occupied in South East of the Selenge province that is $238 \mathrm{~km}$ away from Ulaanbaatar city and $250 \mathrm{~km}$ away from center of the province.

On the basic of the laboratory tests, a scheme flow sheet for the preparation of $\mathrm{TiO}_{2}$, ferrous oxide, and rare earth oxides from polymetallic ore sample has been proposed involving the following main process: milling, sulphuric acid leaching, calcining, hydrochloric acid leaching, water hydrolysis, concentrated sulphuric acid decomposition. The full experimental procedure is shown in Fig.1. 


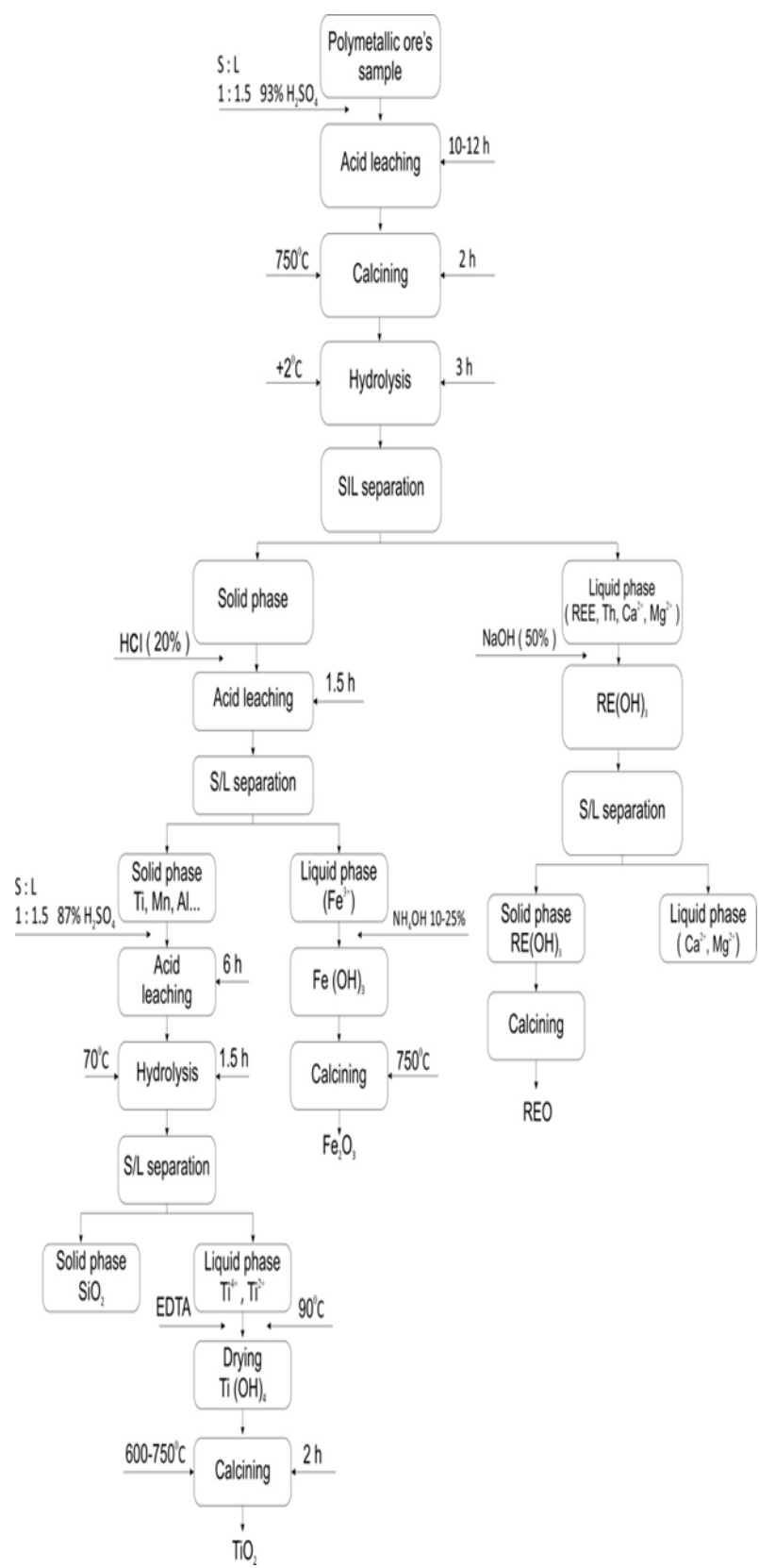

Figure 1. The experimental process of transition metals and rare earth oxides from polymetallic ore

The sample was milled before leaching process. Sulphurization process occurs more efficient when solid phase of the ore and concentrate has been milled in appropriate size. In this research, firstly polymetallic ore was milled by Jaw crusher device to get $3.35 \mathrm{~mm}$, and milled by LM in order to get 75 micro-sized polymetallic ore sample.

We determined optimal conditions of sulphuric acid leaching process. In the sulphate process, the milled sample is treated with a $93 \%$ concentrated sulphuric acid at $140^{\circ} \mathrm{C}$ for $10-12$ hours, where $\mathrm{S}: \mathrm{L}$ ratio is $1: 1.5$. Once sulphate processing completed then it calcined at $750^{\circ} \mathrm{C}$ degrees. (Part I).

After sulphurization and calcining process we are dissoluted the sample in a water with $+2^{0} \mathrm{C}$ temperature and then separated solid and liquid phase. At this step, soluble rare earth sulphates are transferred into liquid phase (REE, Th, $\mathrm{Ca}^{2+}$ and $\mathrm{Mg}^{2+}$ ). Liquid phase contained REE, Th, $\mathrm{Ca}^{2+}$ and $\mathrm{Mg}^{2+}$ is treated with $50 \%$ concentrated sodium hydroxide then solid and liquid phases separeted in order to isolate hydroxides of rare earth metals from other metals. Separated solid phase contained rare earth metals is calcined to extract rare earth oxides. (Part II).

After rare earth metals isolated, the separated solid phase (part I) is treated with a $20 \%$ concentrated hydrochloric acid for 1.5 hours, whereas acid leaching has taken place, whereas iron ionic is in liquid phase.

Process to separating solid and liquid phases repeated again, and a separated solid phase is treated with $87 \%$ concentrated $\mathrm{H}_{2} \mathrm{SO}_{4}$ for 6 hours and then hydrolysis process has carried on at $70^{\circ} \mathrm{C}$ for 1.5 hours in order to remove silica oxide.

At the next stage, $0,1 \mathrm{~mol} / 1$ EDTA solution was added to titanium sulphate solutions. The solution was heated to $90^{\circ} \mathrm{C}$ for $90 \mathrm{~min}$. The precipitate was filtered, washed with deionized water and dried in air at room temperature [6]. The powder was calcined at different temperatures $600^{\circ} \mathrm{C}$ to $750^{\circ} \mathrm{C} 900^{\circ} \mathrm{C}$ for 2 hours [7].

It is well known that EDTA plays a key role in improving the purity. Therefore, we used EDTA for improving the purity of $\mathrm{TiO}_{2}$ particles and EDTA was introduced as an additive to precipitate the precipitation of $\mathrm{Fe}^{3+}$ during the hydrolysis of titanium sulphate, chemical reaction $(3,4)$ follow as [5]. (Part III).

$$
\text { EDTA }+4 \mathrm{OH}^{-}=\mathrm{EDTA}^{4-}+4 \mathrm{H}_{2} \mathrm{O}(3)
$$

$\left[\mathrm{Fe}\left(\mathrm{H}_{2} \mathrm{O}\right)_{6}\right]^{3+}(\mathrm{aq})+\operatorname{EDTA}^{4-}(\mathrm{aq})=[\mathrm{Fe}(\operatorname{EDTA})]^{-}(\mathrm{aq})+6 \mathrm{H}_{2} \mathrm{O}(4)$

Sametime, separated liquid phase containing $\mathrm{Fe}^{3+}$ is treated with 10 to $25 \%$ concentrated $\mathrm{NH}_{4} \mathrm{OH}$ and then calcining process is carried on at $750^{\circ} \mathrm{C}$ to extract ferrous oxide hematite. (Part IV)

Chemical analysis of the selected polymetallic ore sample and extracted transition metal oxides are accurately studied and computed by inductively coupled plasma mass spectrometer (ICP-MS) and full reflecting $\mathrm{X}$-ray flourescence (XRF) spectrometer, minerals analysis determinate by X-ray diffractometer (Enraf Nonius Delft), and mineral morphology structure by Hitachi TM-1000 SEM-EDX a device for analytical method.

\section{Results and discussion}

In the result of the chemical analysis of the polymetallic ore, macro elements such as an iron (Fe-28.12\%), aluminium (Al-9.5\%), titanium (Ti-0.84\%), magnesium (Mg-0.61\%), potassium (K-0.57\%), calcium (Ca-0.71\%) contents are determined by ICP-MS method (Table 1) and quartz $\mathrm{SiO}_{2}$ of silica group, anorthite $\mathrm{CaAl}_{2} \mathrm{Si}_{2} \mathrm{O}_{8}$, albite $\mathrm{NaAlSi}_{3} \mathrm{O}_{8}$, magnetite $\mathrm{Fe}_{3} \mathrm{O}_{4}$ minerals detected by $\mathrm{X}$-ray phase analysis of the sample. Figure 2.

Table 1. Some macro elements chemical content of polymetallic ore sample (\%)

\begin{tabular}{cccccccc}
\hline Elements & $\mathrm{Al}$ & $\mathrm{Ca}$ & $\mathrm{Fe}$ & $\mathrm{K}$ & $\mathrm{Mg}$ & $\mathrm{P}$ & $\mathrm{Ti}$ \\
\hline $\begin{array}{c}\text { Polymetallic } \\
\text { ore's } \\
\begin{array}{c}\text { sample (\%) } \\
\text { (\%) }\end{array}\end{array}$ & 9.5 & 0.71 & 28.12 & 0.57 & 0.61 & 0.03 & 0.84 \\
\hline
\end{tabular}




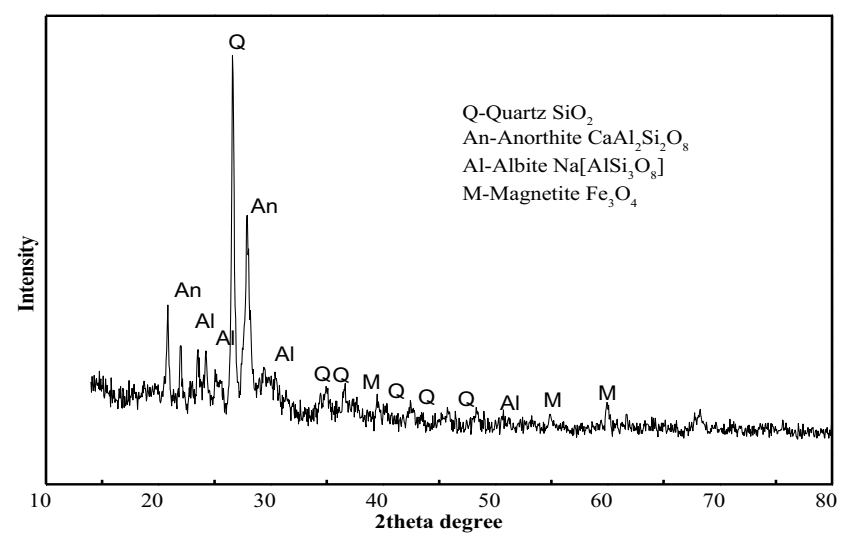

Figure 2. X-ray diffractograms of the polymetallic ore

It is difficult process to carry out if polymetallic ore contains silica group minerals and once sulphate processing takes place where metal minerals in the ore are formed sulphate forms and at sametime as soluble rate increases the process turns out to become much easy. Once sulphate process has carried on polymetallic ore which contained silica group minerals then has calcined at $750^{\circ} \mathrm{C}$. Meanwhile the transition metals, iron and titanium minerals formed into sulphate forms and in the calcining process minerals are eliminated into oxides of the these elements which are richened magnitite $8.16 \%$, hematite $5.96 \%$, rutile $4.52 \%$ that have transferred into solid phase [2].

In the result (part I) of this analysis minerals such as a quartz $\mathrm{SiO}_{2}$, anorthite $\mathrm{CaAl}_{2} \mathrm{Si}_{2} \mathrm{O}_{8}$, albite $\mathrm{NaAlSi}_{3} \mathrm{O}_{8}$ magnitite $\mathrm{Fe}_{3} \mathrm{O}_{4}$, hematite $\mathrm{Fe}_{2} \mathrm{O}_{3}$, rutile $\mathrm{TiO}_{2}$, dickite $\mathrm{Al}_{2}\left[\mathrm{Si}_{2} \mathrm{O}_{5}\right](\mathrm{OH})_{4}$ have detected, which shows that sulphate and calcining processing carried out succesfully figure 3.

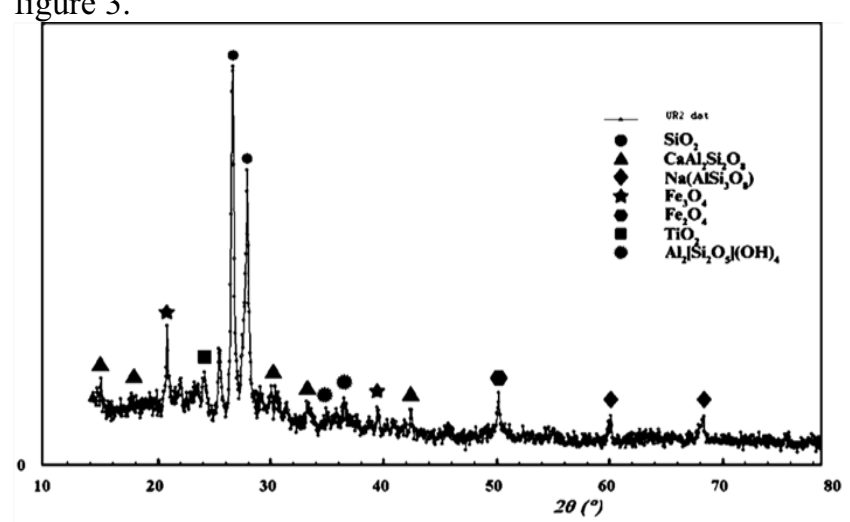

Figure 3. X-ray diffractogram of the sample after sulphate and calcining process of the polymetallic ore

The experimental section part II phase analysis result shown quartz $\mathrm{SiO}_{2}-56.27 \%$, anatase $\mathrm{TiO}_{2}-28.77 \%$, albite $\mathrm{Na}\left[\mathrm{AlSi}_{3} \mathrm{O} 8\right]-7.23 \%$, anorthite $\mathrm{Eu}_{0.92} \mathrm{Al}_{1.76} \mathrm{Si}_{2.24} \mathrm{O}_{8}$ $4.84 \%$ and aeschynite $\mathrm{Ce}(\mathrm{Nb}, \mathrm{Ti})_{2} \mathrm{O}_{6}-2.87 \%$ have been detected by $\mathrm{X}$-ray analysis of rare earth elements oxides extracted at $750^{\circ} \mathrm{C}$ Figure 4.

Cerium oxide content in complex rare earth element oxide was $57.6 \%$ which has been determined by cerimetry.

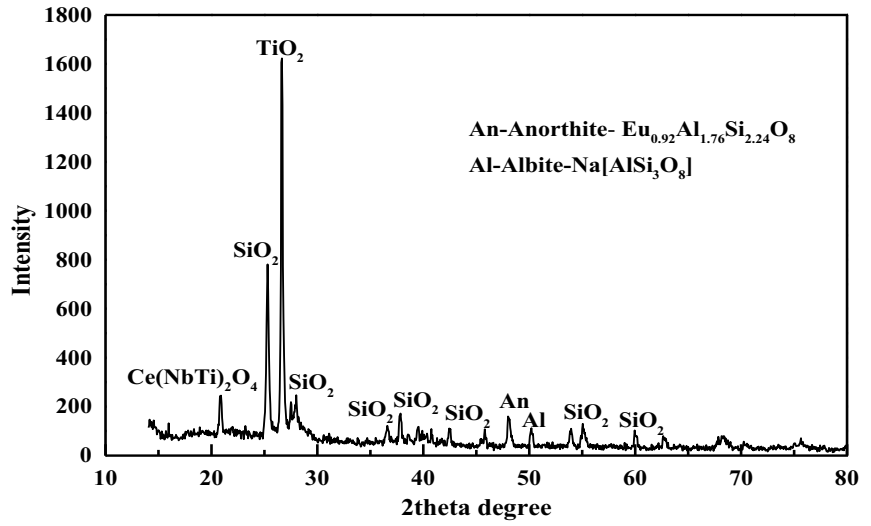

Figure 4. X-ray diffractogram of the extracted total rare earth oxides

The experimental process part III result is shown extracted titanium hydroxide is calcined at $600^{\circ} \mathrm{C}$, $750^{\circ} \mathrm{C}, 900^{\circ} \mathrm{C}$ for 2 hours to extract titanium oxide and $\mathrm{X}$-ray phase analysis carried on to determine crystall structure. As a result of the X-ray phase analysis amorph titanium oxide at $600^{\circ} \mathrm{C}$, polymorph anatase mineral of the titanium oxide $750^{\circ} \mathrm{C}$ and brookite minerals at $900^{\circ} \mathrm{C}$ determined, respectively Figure 5.

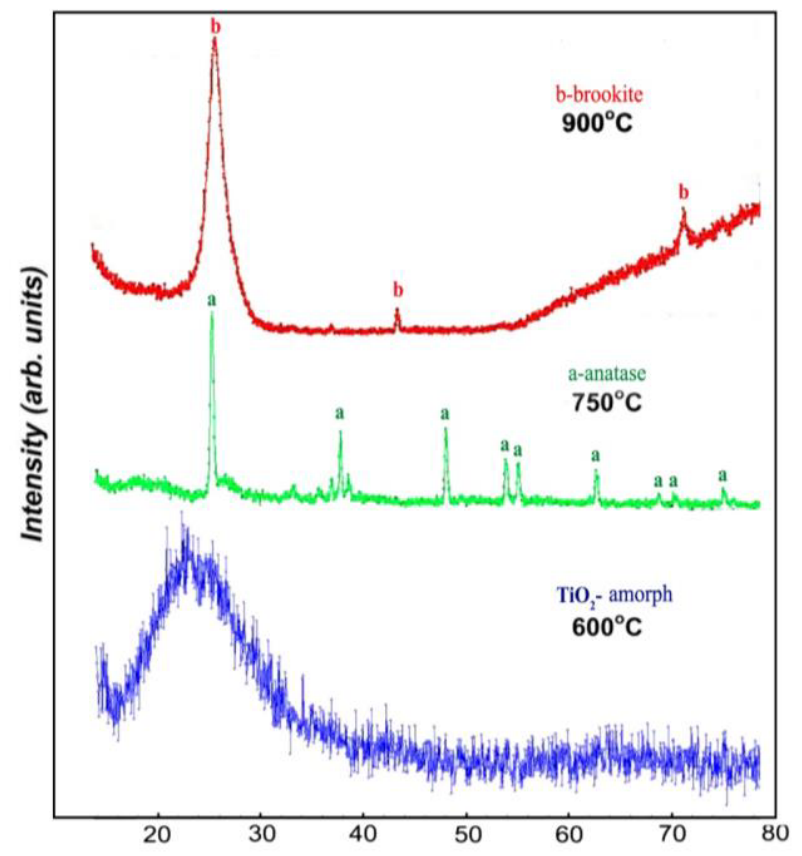

Figure 5. X-ray diffractogram of the extracted titanium dioxide $\mathrm{TiO}_{2}$

Chemical properties of the extracted titanium oxide in the anatase minerals of the titanium oxide extracted at $750^{\circ} \mathrm{C}$ has studied by the analytical method X-ray flourescence.

According to the result of the X-ray flourescence analytical method, macro elements content in sample is $90.9 \%$, which contains titanium oxide $62.5 \%$, aluminium oxide $2.27 \%$, iron oxide $5.46 \%$, sulfur oxide $9.89 \%$ and silicon oxide $4.42 \%$, respectively Table 2 .

According the study of the chemical properties of the brookite mineral of the titanium oxide extracted at 
$900^{\circ} \mathrm{C}$, total macro element content is $99.9 \%$ where titanium oxide content increased to $89.6 \%$. Through the $\mathrm{X}$-ray flourescence analysis has determined that the concentrate contains aluminium oxide $1.17 \%$, iron oxide
$6.7 \%$ sulphur oxide $0.96 \%$ and silicon oxide $1.92 \%$, respective Table 3 .

Table 2. Chemical contents of the extracted anatase mineral

\begin{tabular}{|c|c|c|c|c|c|c|c|c|c|c|c|c|c|c|c|c|c|}
\hline \multirow{2}{*}{$\begin{array}{c}\text { Content } \\
\%\end{array}$} & $\mathrm{Al}_{2} \mathrm{O}_{3}$ & $\mathrm{BaO}$ & $\mathrm{CaO}$ & $\mathrm{CuO}$ & $\mathrm{Fe}_{2} \mathrm{O}_{3}$ & $\mathrm{~K}_{2} \mathrm{O}$ & $\mathrm{MnO}_{2}$ & $\mathrm{Nb}_{2} \mathrm{O}_{3}$ & $\mathrm{Ta}_{2} \mathrm{O}_{3}$ & $\mathrm{ZnO}$ & $\mathrm{ZrO}$ & $\mathrm{P}_{2} \mathrm{O}_{5}$ & $\mathrm{PbO}$ & $\mathrm{SO}_{2}$ & $\mathrm{SiO}_{2}$ & $\mathrm{TiO}_{2}$ & Total \\
\hline & 2.27 & 1.94 & 1.35 & 0.13 & 7.8 & 0.22 & 0.14 & 0.13 & 0.011 & 0.02 & 0.05 & 0.02 & 0.01 & 9.89 & 4.42 & 62.5 & 90.9 \\
\hline
\end{tabular}

Table 3. Chemical contents of the extracted brookite mineral

\begin{tabular}{|c|c|c|c|c|c|c|c|c|c|c|c|c|c|c|c|c|c|}
\hline \multirow{2}{*}{$\begin{array}{c}\text { Content } \\
\%\end{array}$} & $\mathrm{Al}_{2} \mathrm{O}_{3}$ & $\mathrm{BaO}$ & $\mathrm{CaO}$ & $\mathrm{CuO}$ & $\mathrm{Fe}_{2} \mathrm{O}_{3}$ & $\mathrm{~K}_{2} \mathrm{O}$ & $\mathrm{MnO}_{2}$ & $\mathrm{Nb}_{2} \mathrm{O}_{3}$ & $\mathrm{Ta}_{2} \mathrm{O}_{3}$ & $\mathrm{ZnO}$ & $\mathrm{ZrO}$ & $\mathrm{P}_{2} \mathrm{O}_{5}$ & $\mathrm{PbO}$ & $\mathrm{SO}_{2}$ & $\mathrm{SiO}_{2}$ & $\mathrm{TiO}_{2}$ & Total \\
\hline & 1.17 & 0.01 & 0.07 & 0.04 & 6.7 & 1.2 & 0.02 & 0.07 & 0.01 & 0.01 & 0.02 & 0.07 & 0.01 & 0.96 & 1.92 & 89.6 & 99.9 \\
\hline
\end{tabular}

When a morphology structure of the extracted anatase mineral is studied by SEM-EDX analysis, finding presents that the titanium oxide anatase has tetragonal crystal structure and contains many polycrystals, which shown at Figure 6.



Figure 6. Morphology structure of extracted anatase mineral - SEM-EDX

As a by-product of extraction of titanium dioxide process, we have extracted ferrous oxide hematite successfully. (Part IV)

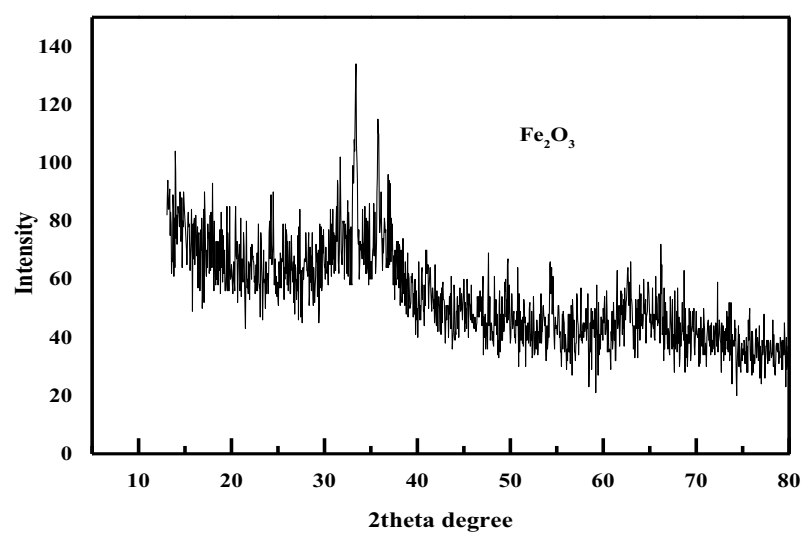

Figure 7. Ferrous oxide X-ray diagram

X-ray phase analysis and chemical analysis shown that ferrous oxide content is $83.8 \%$.

\section{Conclusion}

1. Chemical and mineral analysis of polymetallic ore is carried out basis of responses to the support process at various degrees of water whereas transition metal sulphates solubility differ.

2. As a result of sulphate and resulphurization process we have extracted anatase with 62.5 percent titanium dioxide and brookite mineral with 89.6 percent of titanium dioxide as well as mineral with 83.8 percent of ferrous oxide hematite and rare earth oxides with 57.6 percent of cerium oxide. These oxides are identified under various conditions in the thermal processing.

3. We are currently working in research on utilization of high-purity anatase nanopowder $\left(\mathrm{TiO}_{2}\right)$ with photocatalytic activitiy for treating waste water in order to eliminate its total bacteria, especially E. Coli under UV-A. Highpurity anatase nanopowder has been extracted from anatase with $62.5 \%$ of titanium oxide by recrystalization process.

\section{References}

1. O. Gerald, A.C. Onyedika, Achusim-udenko, Nwoko, Ogwuegbu, Int. J. Chem. Sci. 10,1 112-130 (2012)

2. J. Zoumei, L. Wang, H. Zhou, Zh. Duan, Titanium Extract and Process, The Mineral, Metals \& Materials Society. 122-128, (1997)

3. O. Enkh-Uyanga, B. Munkhtsetseg, J. University of Science and Technology Bulletin. 12, 83-90 (2015)

4. P.M. Kobylin, H. Sippola, P. Taskinen, CALPHAD: Computer Coupling of Phase Diagrams and Thermochemistry. 35, 499-511 (2011).

5. B. Munkhtsetseg, G. Burmaa, AIP Conf. Proc. 1542, 1278 (2013)

6. X. Xiong, Z. Wang, F. Wu, J.Advanced Powder Technology. 24, 60-67 (2013)

7. H. Kominami, Y. Ishii, M. Kohno, S. Konishi, J. Catalysis Letter. 91, 41-47 (2003). 